NASCIMENTO MF; RÊGO ER; NASCIMENTO NFF; SANTOS RMC; BRUCKNER CH; FINGER FL; RÊGO MM. 2015. Correlation between morphoagronomic traits and resistance to ethylene action in ornamental peppers. Horticultura Brasileira 33: 151-154. DOI - http://dx.doi.org/10.1590/ S0102-053620150000200003

\title{
Correlation between morphoagronomic traits and resistance to ethylene action in ornamental peppers
}

\section{Mayana F Nascimento ${ }^{1}$; Elizanilda R Rêgo ${ }^{2}$; Naysa FF Nascimento ${ }^{1}$; Rusthon MC Santos ${ }^{1}$; Claudio H Bruckner $^{1}$; Fernando L Finger ${ }^{1}$; Mailson M Rêgo ${ }^{2}$}

${ }^{1} U F V$, Depto. Fitotecnia 36570-000 Viçosa-MG; mayana_nana@hotmail.com; naysaflavia@hotmail.com; rusthomcortez@hotmail.com; bruckner@ufv.br; ffinger@ufv.br; ${ }^{2}$ UFPB-CCA, Lab. Biotecnologia Vegetal, 58397-000 Areia-PB; elizanilda@cca.ufpb.br; mailson@ cca.com.br

\begin{abstract}
The post-production quality of ornamental peppers can be shortened due to exposure to ethylene. The concentration of this phytohormone at $10 \mu \mathrm{L} / \mathrm{L}$ induces leaf, fruit and flowers abscission, ripening of climacteric fruits, organ senescence, seed germination and seedling growth. We evaluated the correlation between pepper morphoagronomic traits and resistance to ethylene on ornamental peppers. Two genotypes, one resistant (UFPB 132), a susceptible (UFPB 134), and two hybrids (DR x PN; $76 \times$ PN) were utilized to assess the susceptibility or resistance to ethylene. The experimental design was completely randomized, with four replications. First, 19 morphoagronomic characteristics were analyzed when the plants had $30 \%$ of fruits at the ripe stage. At this stage, the pots were transferred to a room at $25^{\circ} \mathrm{C}$ with $8-10 \mu \mathrm{mol} / \mathrm{s} / \mathrm{m}^{2}$ of white fluorescent light. Afterwards, the pots were placed in a $60-\mathrm{L}$ container and treated with ethylene at final concentration of $10 \mu \mathrm{L} / \mathrm{L}$. The plants were exposed to ethylene for 48 hours and then kept at room temperature for further analysis. Afterwards, the number of leaves and fruits was determined at time zero and after 144 hours after end of the ethylene treatment. The Pearson correlation was calculated for each pair of variables and submitted to t-test $(\mathrm{p} \leq 0.05)$. We observed high occurrence of a significant positive correlation $(>0.95)$ between leaf abscission and the anther length, major fruit width, pedicel length, pericarp thickness and dry matter content of the fruits. No significant correlation between fruit abscission and morphological evaluated variables was found. These results show the possibility to use morphological measurements to select plants resistant to leaf abscission induced by ethylene, while for the abscission of fruits, no relation to the morphological parameters evaluated in this experiment was possible to be established.
\end{abstract}

Keywords: Capsicum annuum, ornamental plants, leaf and fruit abscission.

\section{RESUMO}

Correlação entre características morfoagronômicas do etileno em pimenteiras ornamentais

A qualidade pós-produção das pimentas ornamentais pode ser encurtada devido à exposição ao etileno. A concentração de etileno de $10 \mu \mathrm{L} / \mathrm{L}$ no ambiente já induz a abscisão de folhas, o abortamento de frutos e flores, o amadurecimento de frutos climatéricos e a senescência de órgãos, prejudicando a comercialização dos produtos. $\mathrm{O}$ objetivo deste trabalho foi determinar a existência de correlação entre características morfológicas da pimenteira ornamental e a resistência das plantas à queda de folhas e frutos pela ação do etileno. Foram utilizados três genótipos resistentes, um acesso (UFPB 132) e dois híbridos (DR x PN; 76 x PN) e um outro acesso suscetível (UFPB 134). O delineamento utilizado foi inteiramente casualizado, com quatro tratamentos e quatro repetições. Primeiramente, foram analisadas 19 características morfológicas quando as plantas apresentavam $30 \%$ de frutos maduros. Após a caracterização morfológica, os vasos contendo as plantas foram transferidos para uma sala a $25^{\circ} \mathrm{C} \mathrm{com}$ $8-10 \mu \mathrm{mol} / \mathrm{s} / \mathrm{m}^{2}$ de luz fluorescente branca. Em seguida, os mesmos foram colocados num recipiente de $60 \mathrm{~L}$ e tratados com etileno até uma concentração final de $10 \mu \mathrm{L} / \mathrm{L}$. As plantas foram expostas ao etileno durante 48 horas e em seguida mantidas à temperatura ambiente para posterior análise dos efeitos do etileno. Foram feitas contagem do número de folhas e frutos no tempo zero e depois do tratamento com etileno às 144 horas para comparação. A perda de folhas e frutos foi expressa em porcentagem de perda, em relação ao tempo zero, após a exposição. A correlação de Pearson foi calculada para cada par de características. A correlação foi testada utilizando-se o teste $\mathrm{t}(\mathrm{p} \leq 0,05)$. Houve ocorrência de alta correlação positiva significativa $(>0,95)$ entre abscisão das folhas e as características de comprimento da antera, maior diâmetro do fruto, comprimento do pedicelo, espessura do pericarpo e teor de massa seca dos frutos. Não houve correlações significativas entre abscisão dos frutos e as características morfológicas avaliadas. Estes resultados revelam que é possível utilizar medidas morfológicas para selecionar as plantas resistentes à abscisão de folhas induzida pelo etileno, enquanto que para a abscisão dos frutos, não há como relacionar com as variáveis morfológicas avaliadas neste experimento.

Palavra-chave: Capsicum annuum, plantas ornamentais, conservação pós-produção, abscisão de folhas e frutos. 
$\mathrm{T}$ he genus Capsicum belongs to family Solanaceae, tribe Solaneae, subtribe Solanenae, comprising five domesticated species and unknown number of wild species (Heiser, 1979; Casali \& Couto, 1984). The domesticated species and commercially grown are Capsicum annuum, $C$. baccatum, C. chinense, C. frutescens and C. pubescens (Pickersgill, 1971).

In relation to genus Capsicum, Ferrão et al. (2011) reported that pepper fruits have great diversity of color, shape and flavor. The market for pepper is quite diverse, from commercialization for fresh consumption, processing and homemade canning.

Beside its use in cooking, some types of Capsicum peppers are used as ornamental plants, since they have characters which give aesthetic value, as variegated foliage, small canopy, erect and intense fruit color contrasting with green foliage (Carvalho et al., 2006).

Generally, during post-production phase, when the pots are taken to a closed and low-luminosity environment, several factors of this environment affect longevity of plants (Hoyer, 1996). Among these factors, the deleterious effect of ethylene on sensitive varieties is one of the limiting causes to commercialize ornamental peppers. Excess of ethylene in the surrounding environment, plants sensitive to ethylene develop abscission of leaves, flowers and fruits (Serek et al., 2006). Segatto et al. (2013) showed that small concentration of ethylene in the environment, $10 \mu \mathrm{L} / \mathrm{L}$, affected the post-production quality of ornamental C. annuиm varieties. These authors also concluded that ethylene caused leaf abscission and fruit abortion at different levels of intensity, and, stimulated the chlorophyll degradation in the leaves of ornamental peppers.

Mao \& Motsenbocker (2002) showed that both the ripeness as the abscission of fruits in species of $C$. frutescens is regulated by ethylene. Villavicencio et al. (2001) reported that pepper and sweet pepper fruits, from C. frutescens and $C$. annuum, respectively, can be classified as intermediate fruits, between climacteric and non-climacteric, as a result of selection practices in breeding programs and also that the evolution of ethylene and $\mathrm{CO}_{2}$ during ripening is one characteristic of each Capsicum cultivar.

Correlation evaluation between morphoagronomic traits and resistance to ethylene allows the evaluation of quantitative ratio of a character in relation to another. Naguettini \& Pinto (2007) reported that highly correlated variables may not represent cause and effect relationship, but the tendency that the variables present as their joint variation. On the other hand, Ougham et al. (2007), in a review on the control of senescence in plants, reported that senescence is determined by several genes, which act quantitatively and the variability in the synthesis and action of ethylene found in plants affect their morphology and development. Pleiotropy and genetic linkage are causes of correlation between traits (Falconer, 1981) and, according to Cruz \& Regazzi (2001), knowledge of correlations between variables is required at different stages of breeding programs, since most breeding programs take into account many features simultaneously, and the correlation between them can contribute to the choice of the most appropriate selection procedures to maximize genetic gain per generation (Santos \& Vencovsky, 1986; Ferreira et al., 2012). In this sense, this work aimed to evaluate the correlation between morphologic characters and resistance to ethylene in ornamental peppers.

\section{MATERIAL AND METHODS}

The experiment was carried out in a greenhouse, in the laboratory of Plant Biotechnology in Agricultural Science Center of Universidade Federal da Paraíba. Two genotypes (UFPB 132) and (UFPB 134), resistant and susceptible to ethylene, respectively, were used (Figure 1). And two hybrids (DR x PN; $76 \times \mathrm{PN}$ ) resistant to ethylene.

Accessions with identification number in germplasm bank of Universidade Federal da Paraíba 134 and 132 are the varieties Calypso and the accession BGH 7073 (Universidade Federal de Viçosa), respectively. They were pre-selected as patterns of susceptibility and resistance to ethylene, respectively (Segatto et al., 2013). The seeds were sown in polystyrene trays of 128 cells, containing commercial substrate $\left(\right.$ Plantmax $^{\circledR}$ ). The seedling transplanting was performed to plastic pots with capacity of $900 \mathrm{~mL}$, when the seedlings showed from four to six definitive leaves, using the same substrate for seedling production. Morphoagronomic characterization of Capsicum plants was based on quantitative descriptors list recommended by IPGRI (1995). Nineteen quantitative traits were evaluated, when the plants showed 30\% of ripe fruits, as it follows: plant height, first bifurcation height, stem diameter, average leaf length, average leaf width, average leaf petiole length, average corolla length, average petal diameter, average anther length, average filament length, average fruit weight, average fruit length, major fruit width, minor fruit width, average pedicel length, average pericarp thickness, average placenta length, dry mass content and average number of seeds per fruit.

After morphological characterization, the pots were transferred to a room at $25^{\circ} \mathrm{C}$ with $8^{-10}$ $\mu \mathrm{mol} / \mathrm{s} / \mathrm{m}^{2}$ of white fluorescent light. Controls without ethylene were kept in these same conditions for visual comparison of exposed and unexposed plants. Then, the pots were placed in $60 \mathrm{~L}$-sealed containers in the presence of ethylene, at final concentration of 10 $\mu \mathrm{L} / \mathrm{L}$. The plants remained exposed to ethylene for 48 hours, and, afterwards, they were kept at temperature of $25^{\circ} \mathrm{C}$ with $8^{-10} \mu \mathrm{mol} / \mathrm{s} / \mathrm{m}^{2}$ of white fluorescent light, for further analysis of ethylene effects. The plants were analyzed in relation to number of leaves and fruits at time zero (before the treatment with ethylene) and at 144 hours after the treatment with ethylene for leaf and fruit abscission. Loss of leaves and fruits was expressed in percentage, in relation to time zero, after exposure to ethylene. The experimental design used was completely randomized, with four treatments and four replications. For correlation analysis, values in percentage, of number of leaf and fruit abscission, were determined. Data were 
subjected to normality test and, when the normality was detected, Pearson correlation analysis was performed. This was calculated for each pair of traits and values subjected to t-test $(\mathrm{p} \leq 0.05)$. All analyses were performed using computer program Genes (Cruz, 2006).

\section{RESULTS AND DISCUSSION}

Results show occurrence of high significant positive correlation $(>0.95)$ between leaf abscission and anther length, major fruit width pedicel length, pericarp thickness and dry mass content of fruits (Table 1). These data show that the selection of plants with higher values in any of these traits may cause greater leaf fall, since changes caused between these traits and leaf abscission occur by common factors.

Cruz et al. (1988) stated that, in breeding programs, correlation between traits should be taken into account, because changing one trait, by selecting, cause change in another trait related to it. According to Nunes et al. (2008), when the desired character has low heritability or is difficult to evaluate, it is advantageous, in breeding programs, if practice indirect selection, to use another highly correlated character, with high heritability character, and/or easier to evaluate. In the present study, it is possible to state that, in future studies, indirect selection aiming to decrease anther length, major fruit width, petiole length, pericarp thickness and dry mass content traits, result in simultaneous selection of plants with lower leaf abscission caused by the deleterious effects of ethylene. The use of these traits to compose selection indexes may help in obtaining plants resistant to ethylene.

Both leaf (Brown, 1997) and fruit senescence (Mao \& Motsenbocker, 2002) are influenced by ethylene. John et al. (1995) in their work with antisense tomato plants showed that ethylene is directly related to leaf senescence. Davies \& Grierson (1989) showed that several genes related to fruit ripening are expressed during the leaf senescence process, which suggests similarities between leaf senescence and fruit ripening. In fact, these authors report that accumulation of specific mRNA is common to both processes.

Significant correlations between fruit abscission and morphologic traits evaluated were not observed (data not shown). Given the above, occurrence of fruit abscission, after ethylene exposure, would be expected in this work; however Mao \& Motsenbocker (2002) showed that the force required to detach the fruit of the plants was affected by ethylene only when the fruits were at stage 3 of growth (fruit almost fully ripe). In the present study the methodology used by Segatto et al. (2013) was adopted, in which ethylene application occurred when the plants showed $30 \%$ of ripe fruits, simulating the stage when the plants are transported and marketed. As in pepper ripening is gradual, 70\% of fruits would be at stage 1 (completely green fruit) or 2 (color changing from green to red). Fruit senescence might be detected if ethylene treatment had been done later. Due to the fact that the percentage of fruit senescence has been referring to total fruit, and not to total ripe fruit, it may have led, also, to the underestimation of this trait, which may have result in failure to detect the correlation between the application of ethylene and fruit abscission.

Cultivation and commercialization of potted ornamental peppers have been increasing all around the world (Finger et al., 2012). Segatto et al. (2013), in their study with different genotypes of ornamental peppers, showed that ethylene affected longevity of the plants exposed to this hormone. Serek et al. (2006) reported that the sensitivity level of ornamental plants to ethylene is, generally, defined at family level, but, the differences can be found, also, in the same species. Santos et al. (2013) showed the variation, for resistance to ethylene, in segregating population (F2) of ornamental pepper of Capsicum annuum species. Also, according to these authors, the evaluated genotypes showed different percentages of leaf abscission, genotypes totally sensitive to ethylene and other resistant being found, showing that genetic variability, in the same species, can be noticed, as Serek et al. (2006) recommended.

Based on data obtained in this study, we can conclude that in pepper breeding

Table 1. Pearson's correlation among leaf senescence and agronomic characteristics of ornamental peppers (correlação de Pearson entre a abscisão de folhas e características morfoagronômicas de pimenteiras ornamentais). Areia, UFPB, 2012.

\begin{tabular}{lcccccccccc}
\hline $\begin{array}{l}\text { Morphoagronomic } \\
\text { characters }\end{array}$ & AP & APB & DCL & CF & LF & CPF & CC & DP & CANT & CFIL \\
\hline Abscission of leaves & 0.5376 & 0.8047 & 0.5914 & 0.4187 & 0.6154 & 0.6064 & 0.7176 & 0.8012 & $0.9554^{*}$ & 0.9143 \\
\hline & PFR & CFR & MADF & MEDF & CP & EP & CPL & TMS & NSF \\
\cline { 2 - 11 } & 0.5483 & 0.5215 & $0.9807^{*}$ & 0.6299 & $0.9519^{*}$ & $0.9588^{*}$ & 0.2916 & $0.9686^{*}$ & 0.9227 \\
\hline
\end{tabular}

$\mathrm{AP}=$ plant height (altura da planta); $\mathrm{APB}=$ first bifurcation height (altura da primeira bifurcação); $\mathrm{DCL}=$ stem diameter below the first bifurcation (diâmetro do caule abaixo da primeira bifurcação); $\mathrm{CF}=$ average leaf length (comprimento médio da folha); $\mathrm{LF}=$ average leaf width (largura média da folha); $\mathrm{CPF}=$ average pedicel length (comprimento médio do pecíolo); $\mathrm{CC}=$ average corolla length (comprimento médio da corola); $\mathrm{DP}=$ mean petal diameter (diâmetro médio da pétala); $\mathrm{CANT}=$ average anther length (comprimento médio da antera); $\mathrm{CFIL}=$ average fillet length (comprimento médio do filete); $\mathrm{PFR}=$ average fruit weight (peso médio do fruto); $\mathrm{CFR}=$ average fruit length (comprimento médio do fruto); $\mathrm{MADF}=$ maximum average fruit diameter (maior diâmetro médio do fruto); $\mathrm{MEDF}=$ minimum average fruit diameter (menor diâmetro médio do fruto); $\mathrm{CP}=$ average pedicel length (comprimento médio do pedicelo); $\mathrm{EP}=$ average pericarp thickness (espessura média do pericarpo); $\mathrm{CPL}=$ average placenta length); $\mathrm{TMS}=$ dry matter content (teor de matéria seca); $\mathrm{NSF}=$ average number of seeds per fruit (número médio de sementes por fruto); *significant at $5 \%$ by t test (significativo ao nível de $5 \%$ de probabilidade pelo teste t). 

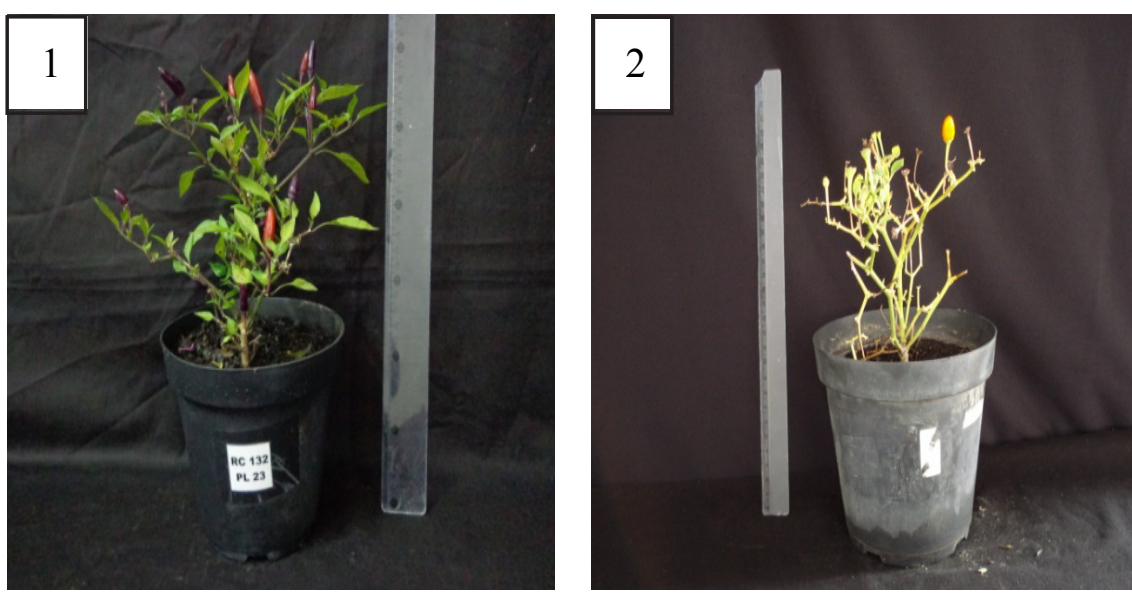

Figure 1. Ornamental pepper cultivars: resistant (1) and susceptible to ethylene (2) 144 hours after ethylene treatment \{cultivares de pimenteira ornamental: resistente (1) e suscetível ao etileno (2), 144 horas após o tratamento com etileno \}. Areia, UFPB, 2012.

programs, for ornamental purpose, plants of smaller fruits and lower pericarp thickness should be selected, since they are more resistant to leaf senescence caused by ethylene.

The authors suggest that, to detect correlation between ethylene sensitivity and fruit senescence, ethylene treatment should be performed when plants have at about $70 \%$ of ripe fruits, stage responsive to ethylene and that fruit abscission percentage would be performed in relation to the total of ripe fruits and not to the total of fruits per plant.

\section{ACKNOWLEDGEMENTS}

The authors thank $\mathrm{CNPq}$ for financial support to projects $474988 / 2008-2$, $311395 / 2009-0,473897 / 2010-5$ and for granting scholarships and research grants.

\section{REFERENCES}

BROWN KM. 1997. Ethylene and abscission. Physiologia Plantarum 100: 567-576.

CARVALHO SIC; BIANCHETTI LB; RIBEIRO CSC; LOPES CA. 2006. Pimentas do gênero Capsicum no Brasil, Embrapa Hortaliças. Embrapa Hortaliças, n. 94, p 27.
CASALI VWD; COUTO FAA. 1984. Origem e botânica de Capsicum. Informe Agropecuário 10: 113 .

CRUZ CD. 2006. Programa genes versão Windows. Aplicativo Computacional em Genética e Estatística. Viçosa: UFV. 648p.

CRUZ CD; MIRANDA JEC; COSA CD. 1988. Correlações, efeitos diretos e indiretos de caracteres agronômicos sobre a produção de pimentão (Capsicum annuum). Revista Brasileira de Genetica 11: 921-928.

CRUZ CD; REGAZZI AJ. 2001. Modelos biométricos aplicados ao melhoramento genético. 2. ed. UFV. 390p.

DAVIES KM; GRIERSON D. 1989. Identification cDNA clones for tomato (Lycopersicon esculentum) mRNA that accumulate during ripening and leaf senescence. Planta 179: 73-80.

FALCONER DS. 1981. Introdução a genética quantitativa. Viçosa: Imprensa Universitária 279p.

FERRÃO RS; CECON PR; FINGER FL; SILVA FF; PUIATTI M. 2011. Divergência genética entre genótipos de pimenta com base em caracteres morfo-agrônomicos. Horticultura Brasileira 29: 354-358.

FERREIRA JP; SCHMIDT O; SCHMIDT ER; PIANTAVINHA WC; CATTANE LF. 2012. Correlações entre características morfoagronômicas de Acessos de mamoeiro. Enciclopédia biosfera-Centro Científico Conhecer 8: 246.

FINGER FL; RÊGO ER; SEGATTO FB; NASCIMENTO NFF; RÊGO MM. 2012. Produção e potencial de mercado para pimenta ornamental. Informe Agropecuário 33: 14-20.
HEISER CB. 1979. Peppers - Capsicum (Solanaceae). In: SIMMONDS NW (ed).. Evolution of crop plants. p. 265-273.

HOYER L. 1996. Critical ethylene exposure for Capsicum annuum 'Janne' is dependent on an interaction between concentration, duration and developmental stage. Journal of Horticultural Science 71: 621-628.

IPGRI. 1995. International Plant Genetic Resources Institute. Descriptors for Capsicum. Rome: IBPGR: $49 \mathrm{p}$.

JOHN I; DRAKE R; FARREL A; COOPER W; LEE P; HORTON P; GRIERSON D. 1995. Delayed leaf senescence in ethylenedeficient ACC-oxidade antisense tomato plants: molecular and physiological analysis. The Plant Journal 7: 483-490.

MAO C; MOTSENBOCKER CE. 2002. Effects of etephon on tabasco pepper fruit ripening and abcission at the fruit receptacle junction. Scientiae Horticulturae 93: 357-365.

NAGUETTINI M; PINTO EJA. 2007. Hidrologia Estatística.Belo Horizonte: CPRM. 561p.

NUNES GHS; BARROS AKA; QUEIROZ MA; SILVA RA; LIMA LL. 2008. Correlações entre características de meloeiro. Caatinga 21: 07-112.

OUGHAM H; ARMSTEAD I; HOWARTH C; GALYUON I; DONNISON I; THOMAS H. 2007. The genetic control of senescence revealed by mapping quantitative trait loci. Annual Plant Reviews 26: 171-201.

PICKERSGILL B. 1971. Relationships between weedy and cultivated forms in some species of peppers (genus Capsicum). Evolution 25: 683-691.

SANTOS J; VENCOVSKY R. 1986. Correlação fenotípica e genética entre alguns caracteres agronômicos do feijoeiro (Phaseolus vulgaris). Ciência e Prática 10: 265-272.

SANTOS RMC; RÊGO ER; NASCIMENTO MF; NASCIMENTO NFF; BORÉM A; FINGER FL; COSTA DS; RÊGO MM. 2013. Ethylene resistance in a $\mathrm{F}_{2}$ population of ornamental chili pepper (Capsicum annuum). Acta Horticulturae 501: 433-438.

SEGATTO FB; FINGER FL; BARBOSA JG; RÊGO ER; PINTO CMF. 2013. Effects of ethylene on the post-production of potted ornamental peppers (Capsicum annuum). Acta Horticulturae 1000: 217-222.

SEREK M; WOLTERING EJ; SISLER EC; FRELLO S; SRISKANDARAJAH S. 2006. Controlling ethylene responses in flowers at the receptor level. Biotechnology Advances 24: 368-381.

VILLAVICENCIO LE; BLANKENSHIP SM; SANDERS DC; SWALLOW LH. 2001. Ethylene and carbon dioxide concentrations in attached fruits of pepper cultivars during ripening. Scientia Horticulturae 91: 17-24. 